\title{
Investment In An Unstable Tax Environment
}

\author{
Sam N. Basu, William Patterson University \\ Franklin Lowenthal, (E-mail Franklin.Lowenthal@csueastbay.Edu), California State University, Eastbay \\ Christopher Lubwama, California State University, Eastbay
}

\begin{abstract}
While most of the capital budgeting situations are typically micro level problems, the introduction of this dual impact of the corporate tax rate on the project acceptance criterion provides an insight into potential tax regime decisions on long term investments in a given tax jurisdiction. If we understand this dual behavior well enough, it might be possible for a tax regime to manipulate its corporate tax rate without necessarily jeopardizing acceptability status of capital projects to providers of capital. The present paper is an attempt to model this dual impact of the corporate tax rate on the NPV of projects within the tax regime, and study the implications of the results for policy makers and for corporations facing such policy makers.
\end{abstract}

\section{INTRODUCTION}

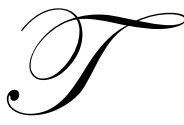

he issue of allocation of scarce resources to long term investment decisions, often called Capital Budgeting in brief, is a very important research and pedagogical topic in Corporate Financial Management [Brigham et al, Bierman and Smidt, Levy and Sarnat, and Seitz and Ellison, among others]. The basic methodology of this allocation process is the time tested Discounted Cash Flow (DCF) approach, where the Net Present Value (NPV) of the potential investment project is estimated by using a methodology that is standard in all corporate finance textbooks. In this typical approach, as we all know, the net after tax cash flows to the project is discounted at the weighted average cost of capital appropriate for the project in question.

The impact of corporate taxes on the project NPV is usually twofold. The corporate tax rate (statutory rate, barring various actual adjustments) affects the after tax cash flow to the project. As this tax rate goes up, the after tax cash flow for a given before tax amount, goes down. However, the corporate tax rate also affects the weighted average cost of capital when the company uses debt capital in its capital structure. For, unlike costs of equity, the after tax cost of debt, (the after tax cost is the one that impacts the project or the corporate weighted average cost of capital) goes down as the tax rate is increased for a given before tax cost of debt. The before tax cost of debt typically is driven by either the capital market, or, in some cases, set by financial institutions and is not directly affected by tax issues. As the weighted average cost of capital is used to discount the after tax cash flows from the project, from a mathematical point of view, it goes into the denominator of the NPV equation. The after tax cash flow itself, however, goes into the numerator of the equation. A change in the corporate tax rate in a tax regime, therefore, has, ceteris paribus, two effects on the NPV. The effect on the cash flow is a direct effect, where the movement of the NPV is in the opposite direction as that of the tax rate, i.e. the higher the tax rate the lower the NPV. The effect on the weighted average cost of capital is also an inverse effect; thus the movement of NPV is now in the same direction as the tax rate since NPV increases with lower discount rates. This non linear two sided interaction between the project NPV and the statutory corporate tax rate could give rise to a potential trade off between the tax rate and the project acceptance criterion.

While most of the capital budgeting situations are typically micro level problems, the introduction of this dual impact of the corporate tax rate on the project acceptance criterion provides an insight into potential tax regime decisions on long term investments in a given tax jurisdiction. If we understand this dual behavior well enough, it 
might be possible for a tax regime to manipulate its corporate tax rate without necessarily jeopardizing acceptability status of capital projects to providers of capital.

The present paper is an attempt to model this dual impact of the corporate tax rate on the NPV of projects within the tax regime, and study the implications of the results for policy makers and for corporations facing such policy makers.

An unstable tax environment in third world nations is a complicating factor in the decision process of multinational corporations. A change in the marginal corporate tax rate can effect both the cash flow from a capital project and the cost of capital used as the discount rate for the net cash flows of the project. In a previous paper Basu et al [1] provided a mathematical sensitivity analysis based on a continuous time NPV model. In this paper we shall extend their analysis of how this result can be used by the host government to develop a flexible tax policy that is still attractive for direct investment by multinational corporations.

\section{PROBLEM}

The critical value of the derivative of the cost of capital with respect to the marginal corporate tax rate is that value at which both the net present value of the project as well as the derivative of the net present value with respect to the marginal corporate tax rate are both zero. At that critical value the investment decision is unaffected by tax rate increases or decreases since the net present value of zero is in fact a local minimum or maximum unless the second derivative were zero, which could only happen in isolated situations.

The crucial mathematical result derived by Basu et al in his previous paper was the formula (1) given below that expresses the critical value of the derivative of the cost of capital with respect to the marginal corporate tax rate as a function of three parameters: $\mathrm{n}$, the life of the investment, $\mathrm{k}$ the cost of capital and $\mathrm{T}$, the marginal corporate tax rate.

This formula was derived by equating $\mathrm{dNPV} / \mathrm{dT}$ to zero at the point where NPV $=0$, "when the investment decision will be unaffected by changes in tax rates $\mathrm{T}$. The magnitude of $\mathrm{dk} / \mathrm{dT}$ for which we can obtain such conditions will give us a range of indifference. This is the critical value for $\mathrm{dk} / \mathrm{dT}$ at which tax rate changes have no impact on the investment decision."

$\mathrm{dk} / \mathrm{dT}=\mathrm{a} *(1+\mathrm{a} /(\mathrm{n} * \mathrm{k})) /(\mathrm{T}-1) *(\mathrm{a} / \mathrm{k}+\mathrm{n} *(\mathrm{a}+1))$

where $\mathrm{a}=\exp (-\mathrm{k} * \mathrm{n})-1$ and the standard operation priorities apply.

We have explicitly computed $\mathrm{dk} / \mathrm{dT}$ from equation (1) for values of $\mathrm{n}$, the life of the investment that vary from 5 to 10 years, $\mathrm{k}$ the cost of capital that varies from $5 \%$ to $15 \%$ and $\mathrm{T}$, the marginal corporate tax rate that is either $30 \%$ or $40 \%$ or $50 \%$. The crucial observation from a close examination of this table is that the values of $\mathrm{dk} / \mathrm{dt}$ are always negative and that its absolute value is for fixed $\mathrm{n}$ and $\mathrm{T}$ an increasing function of $\mathrm{k}$; this can be verified by computing the derivative of (1) with respect to $\mathrm{k}$. The fact that $\mathrm{dk} / \mathrm{dT}$ is negative is a positive incentive for the multinational corporation to undertake the investment even in an environment of increasing marginal corporate taxation by the host government because the decreased cash inflows due to tax rate increases are countered by a decrease in the cost of capital at which these cash flows are discounted. Moreover, the higher the cost of capital is initially, the greater this decrease in the cost of capital for the same increase in the marginal corporate tax rate because of the increase in the absolute value of $\mathrm{dk} / \mathrm{dT}$ as a function of $\mathrm{k}$.

This leads to a surprising and counter-intuitive optimal strategy by the host government. If the initial cost of capital is high, a moderate increase in the marginal corporate tax rate will lead to a substantial decrease in the cost of capital in the region of NPV $=\mathrm{dNPV} / \mathrm{dT}=0$ and therefore not adversely influence the decision mechanism of the multinational corporation considering the investment. 
Journal of Business \& Economics Research - December 2007

Volume 5, Number 12

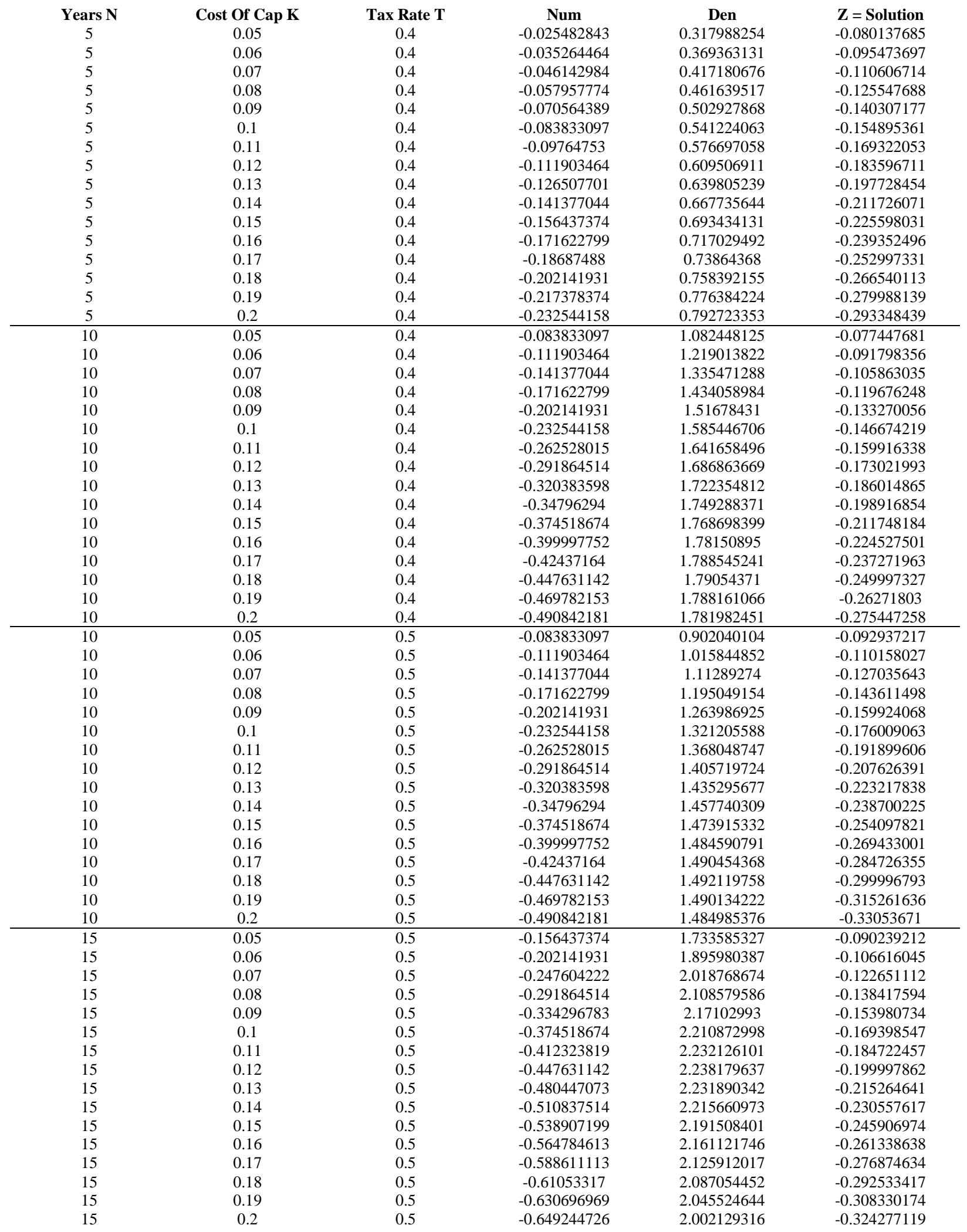


From our tabulated values it also seems that the absolute value of $\mathrm{dk} / \mathrm{dT}$ is for fixed $\mathrm{k}$ and $\mathrm{T}$ a decreasing function of $n$; this means that for projects with a longer life the magnitude of the decrease in the cost of capital as the marginal corporate tax rate increases is not as large as it would be for a project with a shorter life.

\section{COMPARISON EXAMPLE}

Uganda, Tanzania and Kenya have significantly different marginal effective tax rates on cost of production for foreign firms in the tourism industry. They are respectively 30\%, 17\% and 7\% (International Monetary Fund Working Paper, 2000 p. 22). Currently the cost of capital, usually a weighted average of debt, preferred stock and equity capital, in these three nations is approximately 18\% (The Monitor Kampala, Nov 13, 2006 p. 2). From equation (1) we find the respective values of the derivative of the cost of capital with respect to the marginal corporate tax rate to be equal to $-.228,-.193$ and -.172 . On the surface it would appear that Uganda would be the least attractive nation for investment because of the significantly higher tax rate. But Uganda does have an advantage in respect to reducing the cost of capital by increasing the effective marginal tax rate. A 5\% increase in its marginal tax rate from $30 \%$ to $35 \%$ will in fact decrease the cost of capital by over $1 \%\left(5^{*} .228=1.14 \%\right.$ to be exact). A similar 5\% increase in the marginal tax rate of Tanzania from $17 \%$ to $22 \%$ will decrease the cost of capital by a little under $1 \%\left(5^{*} .193=0.96 \%\right.$ to be exact $)$. A similar $5 \%$ increase in the marginal tax rate of Kenya from $7 \%$ to $12 \%$ will decrease the cost of capital by only about $0.85 \%\left(5^{*} .172=0.86 \%\right.$ to be exact). This result is counter to conventional wisdom which would dictate that an increase of the already high marginal tax rate by Uganda would be disastrous in its impact on foreign investment.

\section{CONCLUSION}

In this paper we have extended the mathematical analysis of Basu et al to demonstrate how their result can be used by the host government to develop a flexible tax policy in an unstable corporate tax environment that is still attractive for direct investment by multinational corporations.

\section{REFERENCES}

1. Corporate Investment Decisions and Taxes. Sam N. Basu and James E. Meyer.Proceedings of South Eastern AIDS, February 1976.

2. The Capital Budgeting Decision. Harold Bierman Jr. and Seymour Smidt. ( New York, New York, Macmillan, 1993)

3. Financial Management: Theory and Practice. Eugene F. Brigham and Michael C. Ehrhardt. ( SouthWestern, Thompson Learning Belmont California 2002)

$4 \quad$ Capital Investment and Financial Decisions. Haim Levy and Marshal Sarnat. (Englewood Cliffs, New Jersey, Prentice Hall, 1994)

5 Capital Budgeting and Long Term Financing Decisions. Neil E. Seitz and Mitch Ellison (Fort Worth, Texas, The Dryden Press, 1995) 